\title{
Re-Assessing The Socioeconomic Effects Of The Boko Haram Conflict In A Qualitative Systematic Review
}

https://doi.org/10.21272/sec.3(1).42-51.2019

\section{Oladayo Nathaniel Awojobi}

MA Student, Department of Social Security, Bonn-Rhein-Sieg University of Applied Sciences, Sankt Augustin, Germany

\begin{abstract}
This paper summarizes the arguments and counterarguments within the scientific discussion on the issue of the Boko Haram conflict in Nigeria. The main purpose of the research is to assess the socioeconomic impacts of the Boko Haram uprising. Systematization literary sources and approaches for solving the problem of the social and economic effects of the conflict indicates that there are two main approaches that are important to the Nigerian government to utilize in bringing the conflict to an end. The relevance of the decision of this scientific problem is that the conflict has taken its toll on the Nigerian economy and also affects the social lives of people living within and close to the conflict zone. Investigation of the topic of armed conflict and its socioeconomic impact in the paper is carried out in the following logical sequence: the opening introduction of the negative effects of conflict, followed by a paragraph on conflicts in Africa. Methodological tools of the research methods were a few years of research on the negative impacts of the conflict. The object of research is Nigeria that has experienced armed conflict because the country has been engulfed in the Boko Haram uprising since 2009. The paper presents the results of an empirical analysis of the enormous damage the Boko Haram conflict has done to the social and economic aspects of the Nigerian society which showed that the Nigerian government needs a proactive approach to end the conflict. The research empirically confirms and theoretically proves that armed conflict affects a country's economy as well as the lives of people living close to a conflict zone. The results of the research can be useful for finding a lasting solution to the Boko Haram conflict in Nigeria.
\end{abstract}

Keywords: Boko Haram, conflict, insurgency, socioeconomic, systematic review.

JEL Classification: E62, G21, I10, I12, I31, J12, J64.

Cite as: Awojobi, O. N. (2019). Re-Assessing The Socioeconomic Effects Of The Boko Haram Conflict In A Qualitative Systematic Review. SocioEconomic Challenges, 1(3), 42-51. https://doi.org/10.21272/sec.3(1).42-51.2019.

(C) The Author, 2019. This article is published with open access at Sumy State University.

\section{Introduction}

Armed conflict is a development issue (Gates et al., 2015). Armed conflict kills, and its effects spread much beyond deaths (Gates et al., 2015). War generally contributes to forced migration, protracted refugee complications, and the ruin of social amenities (Gates et al., 2015). Social, political, and economic establishments can be forever ruined (Gates et al., 2015). Armed conflict remains significant in many developing countries and has developed into an essential part of the research of economic development (Serneels and Verpoorten, 2012).

Africa has been known to be a conflict zone due to the reoccurrence of armed conflicts (Aremu, 2010; Ezeoha, 2015). This has contributed to the severe consequences for the development and growth of Africa (Aremu, 2010). Nigeria is one of the countries in Africa that has been engulfed in armed conflicts since the coming of democratic governance in 1999. Notable armed conflicts that Nigeria has experienced in the current democratic dispensation included the Niger-Delta armed struggle, the ethno-religious conflict in Jos, Plateau State, the Fulani Herdsmen armed conflict and the deadly Boko Haram insurgency.

This study is concerned about the socioeconomic effects of the Boko Haram insurgency in the North-east of Nigeria. Since 2009 when Boko Haram originally established its uprising and the outcome of the murder of Mohammed Yusuf the head of the sect, the violent actions of the sect have remained continuous despite the intention of the authority to reduce the atrocity of the armed group (Awojobi, 2014). Boko Haram uses 
kidnapping and molesting of girls as a weapon of war (Awojobi, 2014). The underprivileged are the most casualties of the sect brutalities and the effects of the armed group insurgency fall on the ordinary Nigerians (Awojobi, 2014).

This study employs a qualitative systematic review to assess the socioeconomic effects of Boko Haram insurgency in the northeast of Nigeria. A qualitative systematic review draws together research on a problem, systematically searching for research evidence from primary qualitative studies and bringing the outcome together (Seers, 2015). This study is not aware of any systematic review methodology that had assessed the socioeconomic effects of Boko Haram insurgency and this is the reason for using a qualitative systematic review to assess the correlation between Boko Harm violent crime and its socioeconomic effects. This is the main objective of this review and the research question that is formulated for this review is: what are the socioeconomic effects of Boko Haram insurgency in the northeast of Nigeria?

The remainder of this review is structured as follows. Section 2 discusses the methods used to gather relevant literature. Section 3 presents the results of the systematic review methodology while Section 4 discusses the findings. Section 5 concludes.

\section{Materials and Methods}

This review employs qualitative systematic review methodology to assess the socioeconomic effects of Boko Haram insurgency in the Northeast of Nigeria. This is the first time a systematic review is used to asses Boko Haram atrocities in Nigeria. A systematic review is an analysis of research literature that applies accurate methods to find relevant studies and it uses objective approaches to merge these studies (Rothstein and Borenstein, 2006). According to Rothstein and Borenstein (2006, p. 5), systematic review methodology encapsulates the following:

- Explicit (e.g. in its statement of objectives, materials and methods)

- Systematic (e.g. in its identification of literature)

- Transparent (e.g. in its criteria and decisions)

- Reproducible (e.g. in its methodology and conclusions)

- Unbiased

Systematic reviews are commonly used in the health sciences and later social sciences. However, other disciplines such as the Arts and Humanities are now embracing systematic reviews in their research work. See Fehrmann and Hawkins (2015) for systematic literature review methods for topics in the Humanities.

\section{Systematic search strategy}

A systematic search of research articles was conducted on the web for relevant literature. Specific search items were used to identify literature. These search items include Boko Haram insurgency, Boko Haram in Nigeria, socioeconomic effects of Boko Haram violent crime and the assessment of Boko Haram armed conflict in Nigeria. Google search engine was used for searching the items mentioned above.

\section{Inclusion and exclusion criteria}

Quantitative and qualitative research articles were considered for this review and only those article that investigated Boko Haram insurgency and socioeconomic effects were included. This review also considered studies methods of data collection and theoretical framework. All relevant studies that incorporated data collection methods and theoretical framework were included, and those that did not include these indicators were excluded. Further to this, only research articles that met the study inclusion criteria were included, grey literature, dissertation, newspaper articles, online web articles and report and policy documents were excluded from this review.

\section{Critical appraisal and data extraction}

This review did not use any quality assessment tool rather it employs its own quality assessment mechanism to assess the quality of the included studies. Studies focus, abstracts, data collection methods and data analysis 
were the indicators used to assess the quality of included studies. In terms of data extraction, a form was created where relevant data were stored after rigorous reading of the selected studies.

\section{Data synthesis}

Both quantitative and qualitative studies formed part of this review and it was not possible to use meta-analysis for analysing this review findings. In this case, a narrative synthesis was employed after coding was used to detect salient information. An initial coding was done after reading of the relevant studies that brought out themes. A second coding was undertaken that made it possible for some data that were missed in the initial coding to be included in the themes. A third coding was carried out that allowed all themes to be categorised into categories after detecting similarities and differences of studies. At this stage, a narrative synthesis was used to interpret the primary findings.

\section{Results}

\section{Study selection}

An electronic search for relevant studies produced 100 articles based on titles. The initial screening of these articles led to the 82 articles being excluded and the retaining of 12 full-text articles. An additional screening of abstracts and full-text of the remaining 12 articles resulted in the final retaining of 8 articles. Figure 1 shows the flow diagram of studies identification, screening and included articles.

\section{Study characteristics}

Table 1 encapsulates the characteristics of the 8 studies included. All the studies were done in Nigeria with the concentration of their research in the Northeast of Nigeria where the activities of Boko Haram are predominant. All studies were done within the period of 2014 to 2018. In terms of methodology, 6 studies employed a qualitative analysis while one studied used a quantitative approach.

The included studies used various sources of data collection techniques that range from a questionnaire, interview, online information, historical record to DID. Socioeconomic effects observed by the included studies included economic disruption, displacement, forced migration, unemployment, child malnutrition, education disruption and the destruction of worship centres. Most of the conclusions of the studies focused on Boko Haram insurgency effects on the socioeconomic development of Nigeria.

\section{Socioeconomic effects of Boko Haram insurgency}

Various themes emanated from the analysis which can be subsumed under two wider themes, the social consequences and the economic legacy of conflict. Each broader theme and its sub-themes will now be discussed.

\section{Social consequences}

There are social consequences of armed conflicts wherever they happened. Social consequences of conflicts may include deaths, childhood malnutrition, displacement and business disruption. The section of the review discusses the social consequences of the Boko Haram conflict as reported by the included studies in this review.

\section{Mortality}

War causes deaths. Of the 8 included studies in this review, 4 reported the killing of Nigerians by Boko Haram (Afolabi, 2015; Awojobi, 2014; Mbaya et al., 2017; Othman et al., 2015). Within the period of 2009 to 2014, the killings by Boko Haram fluctuated, the highest number of killings were recorded in 2009, 2011 and 2014 (Afolabi, 2015). Within this period, it was estimated that over 10, 000 people were killed when Boko Haram attacked their targets (Awojobi, 2014; Mbaya et al., 2017). The frequent attacks by Boko Haram and security agencies have killed many civilians in crossfire (Othman et al., 2015).

\section{Destruction of worship centres}

Initially, it was believed that Boko Haram was only interested in attacking only Christians and their worship centres (Afolabi, 2015; Awojobi, 2014). This assumption has been erased going by the reporting of some of the studies reviewed (Afolabi, 2015; Awojobi, 2014; Mbaya et al., 2017; Njoku and Nwachukwu, 2015). The violent attacks of Boko Haram on Christian and Muslim worshipers made people believe that the sect is not only after Christians in its attacks (Afolabi, 2015). The sect continues to attack churches and mosques and 
even killing Moslem clerics who are opposed to their ideology (Awojobi, 2014). From a qualitative study by Mbaya et al., (2017), it was discovered that Boko Haram has killed innocent Muslim clerics, Christians and forcefully converted kidnapped Christians to Muslim faithful. The study also reported that Christian and Muslim worshipers have been bombed and killed in their sanctuaries. Njoku and Nwachukwu (2015) only reported the attack of churches by Boko Haram and the study did not mention an attack on a Muslim worship centre.

\section{Displacement/forced migration}

One main consequence of armed conflict is displacement/forced migration of people. Of the 8 studies reviewed, 4 reported the displacement/forced migration of people due to Boko Haram attacks (Awojobi, 2014; Fehrmann and Hawkins, 2015; Mbaya et al., 2017; Othman et al., 2015). As Boko Haram continues to attack churches, mosques, markets, motor parks, a lot of Nigerians have been displaced or forced to flee their homes (Awojobi, 2014). The National Youth Service Corp (NYSC) that was introduced by the Nigerian government to foster unity among Nigerians has been ridiculed by Boko Haram insurgency (Awojobi, 2014; Fehrmann and Hawkins, 2015). This is because many of the southern Corp members who are serving in the northeast of Nigeria where Boko Haram activities are predominant are forced to be redeployed to states in the southern part (Fehrmann and Hawkins, 2015). Just are southern NYSC members are relocating from the northern part to the southern part, most southerners that have been residing in the northern part for many years have been moving to the south due to Boko Haram (Fehrmann and Hawkins, 2015; Mbaya et al., 2017; Othman et al., 2015).

\section{Education disruptions}

Aside from the killing of people by Boko Haram, one major effect of the Boko Haram conflict is the disruptions of educational activities in the northeast. Around 5 studies reported how Boko Haram attacks have crippled educational activities in the combat zone (Afolabi, 2015; Awojobi, 2014; Familusi and Oshomoh, 2018; Mbaya et al., 2017; Othman et al., 2015). In Maiduguri, Boko Haram has burnt many schools and many other schools are forced to suspend academic activities including the University of Maiduguri (Afolabi, 2015). In Chibok Local Government Area, Boko Haram carried an unprecedented attack in a Federal Government Girls College where over 250 schoolgirls were abducted (Awojobi, 2014). According to Familusi and Oshomoh (2018), education is worst attack by Boko Haram, many school teachers and students have been killed and many school pupils and students have been forced to stay away from school. This has made school enrolment dropped drastically in the Northeast (Mbaya et al., 2017). It is also reported that aside from the attacks on military formations, police stations and prisons, one of the main targets of Boko Haram is school buildings (Othman et al., 2015). This is because Boko Haram is against Western education and it considered it to not Islamic (Familusi and Oshomoh, 2018).

\section{Children, girls and women}

In violent conflicts, children, girls and women are the most affected because of their vulnerability. Five studies have found children, girls and women being victims of Boko Haram violent conflict (Afolabi, 2015; Awojobi, 2014; Dunn, 2018; Familusi and Oshomoh, 2018; Mbaya et al., 2017). Due to the continuous attacks on educational facilities and the disruption of academic activities by Boko Haram, parents have withdrawn their children from schools (Afolabi, 2015). Boko Haram has been kidnapping girls, women and children and using them as a human shield against military onslaught (Awojobi, 2014). Further to this, women are the most victims of Boko Haram rampage kidnapping and some of these women are sexually abused and, in some cases, these women are forcefully married to Boko Haram commanders and their foot soldiers (Awojobi, 2014). Empirical evidence from another study also reports that Boko Haram conflict affects child health. The analysis of the study also projects with a high degree of significance that the likelihood of childhood wasting would have reduced by 13 percentage points if the conflict had not occurred (Dunn, 2018). For Familusi and Oshomoh (2018), the future of many children in areas that are predominant to Boko Haram conflict is in jeopardy because many of the children cannot go to school. Furthermore, the conflict has affected family setting that made the men not to able to trace their wives and the women cannot trace their children (Mbaya et al., 2017).

\section{The economic legacy of Boko Haram conflict}


Protracted civil strife is 'development in reverse' (Collier et al., 2003, p. 13). During armed conflicts, the economy suffered a lot. The following are some economic consequences of the Boko Haram insurgency in the Northeast of Nigeria.

\section{Economic decline}

The decline of economic activities is reported by seven but one of the included studies (Afolabi, 2015; Awojobi, 2014; Bello et al., 2018; Familusi and Oshomoh, 2018; Mbaya et al., 2017; Njoku and Nwachukwu, 2015; Othman et al., 2015). From a qualitative interview, many of the respondents significantly agreed that Boko Haram activities have reduced economic activities in the Northeast (Afolabi, 2015). In Maiduguri, the Borno State capital, the biggest Monday Market was badly affected by the insurgency as shop owners had to close their businesses and left the belligerent city (Awojobi, 2014). A survey research design adopted by Bello et al. (2018), reveals that over $84 \%$ of the respondents of the study subscribed to the notion that there is a significant relationship between Boko Haram insurgency and the decline of business activities in the northeast. The findings of the study suggest that Boko Haram insurgency could alter business investment, the entire business establishment or some situation of its operations include production marketing, finance and human resource (H/R). Most of the businessmen and women who have been affected by the conflict in the northeast have left the affected areas have reinvested their capital in other major cities in Nigeria (Familusi and Oshomoh, 2018). Using analysis of variance (ANOVA) method of analysis by Njoku and Nwachukwu (2015), the findings of the study suggest that Boko Haram insurgency poses a real threat to the Nigerian economy. The results of the study corroborated the work of Othman et al. (2015), whose findings reveal that over 10,000 shops have been closed due to the activities of Boko Haram.

Banks play a vital role in a country's economy and during violent conflicts banking operations are disrupted. Three studies mentioned the disruption of banking operations in the conflict zone (Awojobi, 2014; Familusi and Oshomoh, 2018; Mbaya et al., 2017; Othman et al., 2015). In the affect areas of the conflict, banks no longer operate on the normal banking hours. Instead the banks open for business for just four hours, 9 am to 12 noon, this is to safeguard their operations (Familusi and Oshomoh, 2018). The cost of doing business in the conflict zone has also risen as reported by (Bello et al., 2018; Othman et al., 2015). Another economic activity that has been affected by the conflict is agriculture as reported by 2 studies (Familusi and Oshomoh, 2018; Mbaya et al., 2017). The rumour that spread like a wildfire that Boko Haram planned to poison agricultural products affected the consumption of some agricultural products from the northeast to southern cities (Familusi and Oshomoh, 2018). In Konduga Local Government Area of Borno State, the Alua dam that is economical to the inhabitants of the local government in terms of fishing and farming has been abandoned for more than 6 years affecting the livelihoods of the inhabitants (Mbaya et al., 2017).

\section{Infrastructure}

The most vivid effect of armed conflict is the destruction of public amenities. Of the 8 included studies, 4 reported the destruction of amenities/property/infrastructure (Awojobi, 2014; Familusi and Oshomoh, 2018; Mbaya et al., 2017; Othman et al., 2015). Boko Haram has destroyed markets, police stations, educational institutions, telecommunication masts and other valuable properties. This has resulted in the over-stretching of available facilities and social services in the conflict areas (Mbaya et al., 2017).

\section{Government spending}

In civil wars, government spending increases astronomically because the government uses all resources at its disposal to end the rebellion. Three studies reported the increase in financial spending by the Nigerian government to curtail Boko Haram insurgency (Afolabi, 2015; Familusi and Oshomoh, 2018; Othman et al., 2015). A qualitative interview of respondents by (Afolabi, 2015) reveals that an overwhelming majority of the respondents agreed that the Nigerian government has spent a huge sum of money to finance the war. A historical analysis of the Boko Haram conflict indicates that as at 2016, the conflict has cost the Nigerian economy 1.3 trillion and part of the fund has been used to replace infrastructure that has been destroyed by Boko Haram (Familusi and Oshomoh, 2018). Similarly, a qualitative study by Othman et al. (2015) reveals that funds that would have used to develop critical sectors are now being used to finance the Boko Haram war.

\section{Miscellaneous effects}


Table 2 presents some socioeconomic effects of Boko Haram insurgency as suggested by the findings of the sample studies in this review.

\section{Discussion}

This study is a qualitative systematic review, and it is the first systematic review that assesses the socioeconomic effects of Boko Haram insurgency in Nigeria. This is because the review is not aware of any systematic review that has assessed the socioeconomic effects of the Boko Haram conflict. The research question that emanated from the review is "what are the socioeconomic effects of Boko Haram insurgency in the northeast of Nigeria?" Eight studies were included in this review because they met the inclusion criteria and all, but one employed qualitative methods. Only one study used a quantitive approach, and it measured child malnutrition in the conflict zone.

The social effects of civil war are enormous. Most of the included studies reported various social effects that have emanated from the conflict. The findings from this review reveal that the conflict has led to the death of both civilians and military personnel. In armed conflict, both civilians and combatants are prone to be causalities. Adults mortality are likely to have occurred because of adult's greater vulnerability to the risk of combat deaths, "few of these adult deaths are directly combat related" (Collier et al., 2003, p. 24). A juxtaposition of these surges in mortality with the projections of deaths as a leading result of combat affirms that the death of combatants is merely a secondary factor of the overall increases in mortality (Collier et al., 2003). These increases indicate that wars kill much more civilians than they kill combatants during the conflict (Collier et al., 2003). The findings of this review reveal that none of the included studies actual gives the figures of civilians or combatants that have died in the conflict. This will make it difficult to support the hypothetical statement of Collier et al. (2003) that stated that more civilians are killed in civil wars than the combatants.

While adults are likely to die in civil wars, children, girls and women are not exempted from death because of their vulnerable nature. This review findings reveal that children, girls and women are major victims of Boko Haram insurgency. Studies have supported these findings, in the south and west Darfur, a report in 2005 by the charity Médecins Sans Frontières mentioned approximately 500 cases of rape against women and children (The Economist, 2009). The UN also reported that in eastern Congo, between June 2007 and June 2008, in Ituri province, 6,766 cases of rape were reported, with $43 \%$ involving children (The Economist, 2009). The Boko Haram conflict has affected children, girls and women because they have been kidnapped, raped and killed. Health is a major issue in conflict zones, only one study mentioned child health among the studies and there was no mentioning of attacks on health facilities by any of the included studies.

Displacement or forced migration and the disruption of educational activities were mentioned by some included studies as parts of the social effects of the insurgency. According to the UN Refugee Agency, war and violence globally are causing more people than ever to be forcibly displaced (UNHCR, 2017). Findings from some included studies show that many Nigerians have been displaced by the conflict. While those Nigerians from the southern part have relocated to the major cities in the southern part, the indigenes in the conflict zone have been housed in camps. Most often these camps have become major targets by Boko Haram fighters.

The effect of civil war on education is visible. "Education is the most powerful weapon which you can use to change the world - Nelson Mandela (Signé, 2018). Boko Haram, the Islamist radical group is terrified by this edifying power of education (Signé, 2018). That is why the findings of this review show that Boko Haram has destroyed school buildings, kidnapped students, killed lecturers and students. The attacks on schools have put fear on parents and students. Many schools have been shut and students have stopped going to school. This has drastically reduced enrolment and attendance rates in the northeast. The consequences of the conflict have reduced government educational expenditures. Funds would have been used for educational development are being used to execute the war and rebuild amenities that have been destroyed.

The findings of this review show that aside from the social effects of the Boko Haram conflict, the economy of the northeast has been crippled by the insurgency, Notably, economic decline, the destruction of infrastructure and government financing of the conflict are the major economic consequences of the conflict. Setting away from the very substantial human cost, armed conflict has severe economic costs - loss of houses, amenities, a decrease in the working population, anxiety, a rise in deficit and disruption to regular economic activity (Pettinger, 2017). Though from some aspects, armed conflict can also be profitable in terms of generating 
demand, employment, innovation and profits for business (Pettinger, 2017). None of the included studies in this review shows that the Boko Haran conflict has been beneficial in any way. Instead, findings from this review show the enormous consequences of the conflict.

This review assesses the socioeconomic effects of Boko Haram conflict, eight studies were included in the review. The review encountered some limitations. Firstly, the included studies were not of high qualities which made their findings to be clumsy. Secondly, most of the study use limited data collection methods which affect the quality of their findings' interpretation. Finally, most studies rely on secondary data and this obstructs the evidence of their findings.

\section{Conclusion}

This review evaluates the socioeconomic effects of Boko Haram insurgency in Nigeria with the research question, "what are the socioeconomic effects of Boko Haram insurgency in the northeast of Nigeria?" The findings of the first systematic review revealed that Boko Haram insurgency affects the social and economic life of people in the conflict zone. However, none of the included studies where able to establish if the effects of the insurgency were with high degrees.

The insurgency affects all categories of people through income loss, displacement, kidnapping, rape educational disruption and the loss of lives. In terms of economic consequences, the insurgency has brought about economic decline in the northeast, destruction of infrastructure and it has led to government spending more to execute the war at the expense of other social development.

While this evaluation study is a systematic review that included low and middle-quality studies, a comprehensive evaluation study is needed to ascertain the true state of the socioeconomic effects of Boko Haram conflict. For instance, studies need to be done on the mortality level for both civilians and combatants, the health status of people in the conflict zone, numbers of educational facilities that have been destroyed and what is the actual cost of financing the war.

In sum, this review intends to add to the debate on the socioeconomic consequences of conflict. While the conflict in the northeast continues to take its toll on the Nigerian economy and the people living in the conflict zone, the Nigerian government is left with two options to bring the conflict to an end. Firstly, the government should initiate a serious dialogue with relevant stakeholders to end the conflict. Secondly, if dialogue fails to bring the conflict to an end, the government should embark on a full-scale war to stop the conflict. If Nigerian soldiers can effectively contribute in bringing the civil wars in Liberia and Sierra Leone to an end, they can also end the 9-year-old conflict in the northeast if all saboteurs hindering the execution of the war are dealt with. The Nigeria government has the manpower and resources to end the war, it just needed the political and military will to do so.

\section{References}

1. Bauernschuster. S., Driva, A., Hornung, E. (2017). Bismarck's health insurance and its impact on mortality | VOX, CEPR Policy Portal [Internet]. [cited 2018 Nov 4]. Available from: https://voxeu.org/article/bismarck-s-health-insurance-and-its-impact-mortality.

2. Chubike, N.E. (2013). Evaluation of National Health Insurance Scheme (NHIS) awareness by civil servants in Enugu and Abakaliki. Int J Med Med Sci, 5(7), 356-358.

3. Spaan, E., Mathijssen, J., Tromp, N., McBain, F., ten Have, A., Baltussen, R. (2012). The impact of health insurance in Africa and Asia: a systematic review. Bull World Health Organ, 90(9), 685-692.

4. Adewole D, Bolarinwa O, Dairo M. (2016). National Health Insurance Scheme and Universal Health Coverage among Formal Sector Employees in Ilorin, Nigeria: Has Any Progress Been Made? Int J Trop Dis Health, 18(4), 1-10.

5. Onyedibe, K.I., Goyit, M.G., Nnadi, N.E. (2012). An evaluation of the national health insurance scheme (NHIS) in Jos, a north-central Nigerian city. Glob Adv Res J Microbiol, 1(1), 5-12.

6. Osuchukwu, N.C., Osonwa, K.C., Eko, J.C., Uwanede, C.C., Abeshi, S.E., Offiong, D.A. (2013). Evaluating the Impact of National Health Insurance Scheme on Health Care Consumers in Calabar Metropolis, Southern Nigeria. Int J Learn Dev, 3(4), 30.

7. Porter, J.J., Dessai, S., Tompkins, E.L. (2014). What do we know about UK household adaptation to climate change? A systematic review. Clim Change, 127(2), 371-379. 
8. Ham-Baloyi, W., Jordan, P. (2016). Systematic review as a research method in post-graduate nursing education. Health SA Gesondheid, 21, 120-128.

9. Eyong, A.K., Agada, P.O., Asukwo, E.O., Irene, C. (2016). Awareness of National Health Insurance Scheme (NHIS) and Quality of Health Care Services among Civil Servants in Cross River State, Nigeria. Res Humanit Soc Sci, 6(13), 1-10.

10. Apeloko, O.D. (2017). Health Insurance Scheme (NHIS) in Nigeria: An Empirical Survey. Int J Polit Good Gov, 8(8), 1-25.

11. Adewole, D., Osungbade, K. (2016). Nigeria National Health Insurance Scheme: A Highly Subsidized Health Care Program for a Privileged Few. Int J Trop Dis Health, 19(3), 1-11.

12. Ele, G.N., Ochu, U., Odili, V., Okechukwu, R., Ogbonna, B. (2016). Evaluation of the Benefits, Quality of Services and Challenges to the Nigerian National Health Insurance Scheme among Enrollees in a Tertiary Teaching Hospital in Southeast Nigeria. J Adv Med Pharm Sci, 9(3), 1-11.

13. Owumi, B.E., Omorogbe, C.E., Raphael, S.C. (2013). An Evaluation of the Impacts of the National Health Insurance Scheme on the Employees' Health Status at the University of Ibadan. Afr J Soc Sci, 3(3), 40-52.

14. Ele, G.N., Brian, O., Uche, M., Valentine, U. (2017). Assessment of National Health Insurance Scheme's (NHIS) Effectiveness in a Tertiary Teaching Hospital in Southeast Nigeria. J Adv Med Pharm Sci, 13(3), $1-9$.

15. Mgbe, C.G., Kevin, E.M. (2014). Evaluation of National Health Insurance Scheme: Benefits and Challenges in Eastern Nigeria: A Case Study. South Am J Public Health, 2(4), 491-506.

16. Owumi, B.E., Adeoti, A.B., Taiwo, P.A. (2013). National Health Insurance Scheme Dispensing Outreach and Maintenance of Health Status in Oyo State. Int J Humanit Soc Sci Invent, 2(5), 37-46.

17. Akande, T., Salaudeen, A., Babatunde, O. (2011). The effects of national health insurance scheme on utilization of health services at Unilorin Teaching Hospital staff clinic, Ilorin, Nigeria. Health Sci J., 5(2), 9.

18. Adewole, D.A., Dairo, M.D., Bolarinwa, O.A. (2016). Awareness and Coverage of the National Health Insurance Scheme among Formal Sector Workers in Ilorin, Nigeria. Afr J Biomed Res, 9, 1-10.

19. Saksena, P., Antunes, A.F., Xu, K., Musango, L., Carrin, G. (2010). Impact of mutual health insurance on access to health care and financial risk protection in Rwanda. Geneva, Switzerland: World Health Organization; p. 1-10.

20. Jembere, M.Y. (2018). The Role of Community Based Health Insurance Scheme on Financial Protection and Healthcare Seeking Behavior of Households in Tehuledere District, Northeast Ethiopia. Int J Health Econ Policy, 3(2), 13.

21. Abuosi, A.A., Domfeh, K.A., Abor, J.Y., Nketiah-Amponsah, E. (2016). Health insurance and quality of care: Comparing perceptions of quality between insured and uninsured patients in Ghana's hospitals. Int J Equity Health, 15(76), 2-11.

22. Wang, Z., Li, X., Chen, M., Si, L. (2018). Social health insurance, healthcare utilization, and costs in middle-aged and elderly community-dwelling adults in China. Int J Equity Health, 17(17), 2-13.

23. Ataguba, J.E.-O., Goudge, J. (2012). The Impact of Health Insurance on Health-care Utilisation and Outof-Pocket Payments in South Africa. Geneva Pap Risk Insur - Issues Pract, 37(4), 633-564.

24. Michael, G.C., Suleiman, H.H., Grema, B.A., Aliyu, I. (2017). Assessment of level of satisfaction of national health insurance scheme enrolees with services of an accredited health facility in Northern Nigerian. Ann Trop Med Public Health, 10(5), 1271.

25. Quynh, N.T.N., Dhar, N. (2014). A study of satisfaction among poor patients holding health insurance card with health care services at two district public hospitals in vietnam. Health Popul - Perspect Issues, $37(1$ and 2), 50-56.

26. Mohammed, S., Sambo, M.N., Dong, H. (2011). Understanding client satisfaction with a health insurance scheme in Nigeria: factors and enrollees experiences. Health Res Policy Syst, 9(20), 2-8.

27. Long, S.K, Dimmock, T.H. (2015). Consumer Satisfaction with Health Insurance Coverage in Massachusetts. AMA J Ethic, 17(7), 656-664.

28. Orok, D.A., Usang, A.I., Ikpan, O.O., Duke, E.E., Eyo, E.E., Ekup, E.U., et al. (2016). Prevalence of Malaria and Typhoid Fever Co-infection among Febrile Patients Attending College of Health Technology Medical Centre in Calabar, Cross River State, Nigeria. Int J Curr Microbiol Appl Sci, 5(4), 825-835. 
29. Andefiki, U., Ibrahim, A., Ushie, E.F. (2014). Prevalence of Malaria and Typhoid Fever Co-infection and the Haematological Profile of Patients Attending Hospitals in Wukari Taraba State, Nigeria. AASCIT J Biosci, 3(6), 79-86.

30. Akande, T., Adekunle, S., Babatunde, O. (2011). The effects of national health insurance scheme on utilization of health services at unilorin teaching hospital staff clinic, ilorin, nigeria. Health Sci J, 5(2), 98-106.

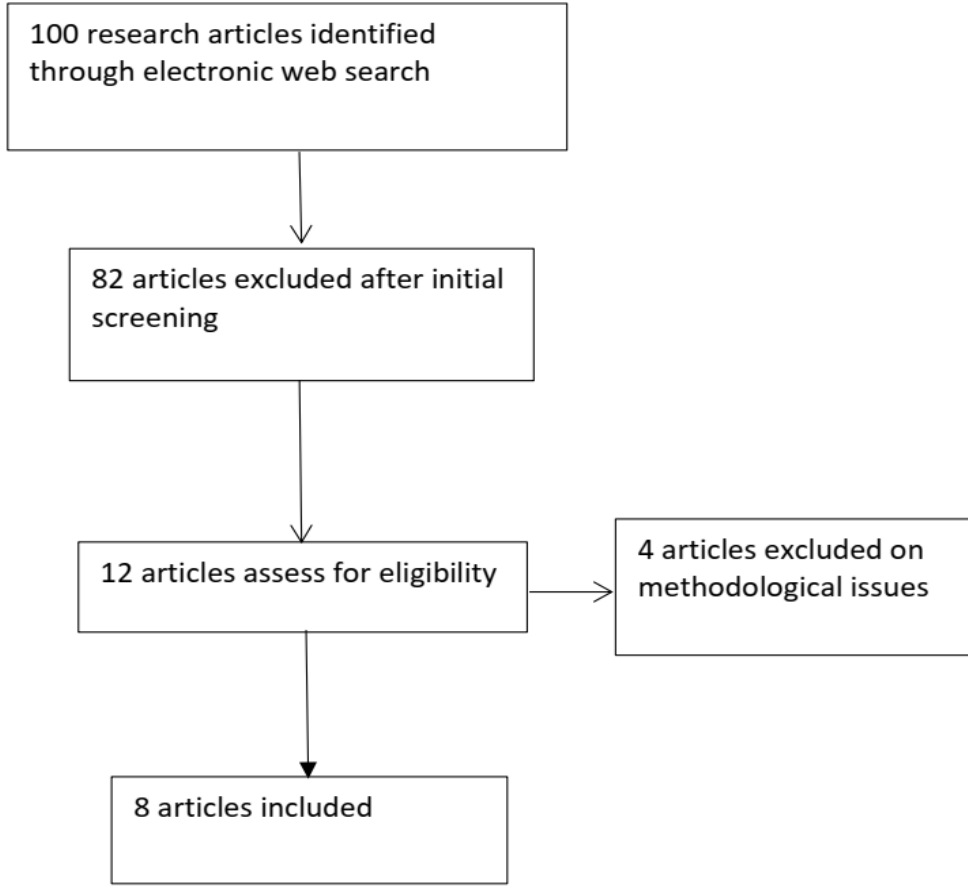

Figure 1. Flow diagram of the systematic review 
Table 1. Key characteristics of studies included in systematic review of studies on the socioeconomic effects of Boko Haram insurgency

\begin{tabular}{|c|c|c|c|c|c|}
\hline Study & Study objective(s) & Methods & $\begin{array}{l}\text { Data collection } \\
\text { technique(s) }\end{array}$ & $\begin{array}{l}\text { Socioeconomic effect(s) } \\
\text { considered }\end{array}$ & Comments/conclusion \\
\hline Afolabi, 2015 & $\begin{array}{l}\text { Reviewing the effect of } \\
\text { Boko Haram insurgence } \\
\text { and its implications on } \\
\text { socio-political economic } \\
\text { in Nigeria }\end{array}$ & Qualitative & Questionnaire & $\begin{array}{l}\text { Business, economic decline, } \\
\text { military spending, education }\end{array}$ & $\begin{array}{l}\text { The findings suggest that } \\
\text { both religious and political lead- } \\
\text { ers promote the activities of } \\
\text { Boko Haram due to bad govern- } \\
\text { ance }\end{array}$ \\
\hline Awojobi, 2014 & $\begin{array}{l}\text { This paper examines the } \\
\text { implications of the oper- } \\
\text { ations of the Boko Ha- } \\
\text { ram insurgency in the } \\
\text { northeast of Nigeria }\end{array}$ & Qualitative & Secondary source & $\begin{array}{l}\text { Mortality, infrastructure, } \\
\text { commercial business, dis- } \\
\text { placement, forced migra- } \\
\text { tion, girls and women, edu- } \\
\text { cation, worship house }\end{array}$ & $\begin{array}{l}\text { The findings reveal that the ac- } \\
\text { tivities of Boko Haram consti- } \\
\text { tute a threat to the development } \\
\text { of Nigeria }\end{array}$ \\
\hline Bello et al. 2018 & $\begin{array}{l}\text { The paper is focused to } \\
\text { investigate the Boko-Ha- } \\
\text { ram revolt since it creates } \\
\text { economic challenges and } \\
\text { severely reduces the } \\
\text { business activities from } \\
\text { the concerned north-east- } \\
\text { ern states of Nigeria }\end{array}$ & Qualitative & $\begin{array}{l}\text { Structured } \\
\text { interview }\end{array}$ & $\begin{array}{l}\text { Commercial business, cost } \\
\text { of doing business }\end{array}$ & $\begin{array}{l}\text { The findings disclosed that there } \\
\text { was substantial link between the } \\
\text { variables and hence a direct ef- } \\
\text { fect involved between Boko-Ha- } \\
\text { ram insurgency and the dwin- } \\
\text { dling business activities in the } \\
\text { north-eastern states of Nigeria }\end{array}$ \\
\hline Dunn, 2018 & $\begin{array}{l}\text { This study explores the } \\
\text { relation between fierce } \\
\text { conflict and childhood } \\
\text { wasting in Northeast } \\
\text { Nigeria }\end{array}$ & Quantitative & $\begin{array}{l}\text { Difference-in- } \\
\text { Difference (DID) }\end{array}$ & Children health & $\begin{array}{l}\text { Descriptive evidence indicates } \\
\text { that poor child health outcomes } \\
\text { in the conflict zones of North- } \\
\text { east Nigeria may be owing to in- } \\
\text { terruptions to social services and } \\
\text { increased food insecurity }\end{array}$ \\
\hline $\begin{array}{l}\text { Familusi and } \\
\text { Oshomon, } 2018\end{array}$ & $\begin{array}{l}\text { This paper investigated } \\
\text { Boko Haram insurgence } \\
\text { and the obstacles it poses } \\
\text { to the socioeconomic de- } \\
\text { velopment of Nigeria }\end{array}$ & Qualitative & $\begin{array}{l}\text { Historical record, } \\
\text { oral interview, sec- } \\
\text { ondary source }\end{array}$ & $\begin{array}{l}\text { Force migration, commer- } \\
\text { cial business, capital flight, } \\
\text { displacement, education, } \\
\text { government spending }\end{array}$ & $\begin{array}{l}\text { The findings reveal that Boko } \\
\text { Haram has activities have done } \\
\text { more damage on socioeconomic } \\
\text { activities, slowing growth and } \\
\text { development in Nigeria }\end{array}$ \\
\hline $\begin{array}{l}\text { Mbaya et al. } \\
2017\end{array}$ & $\begin{array}{l}\text { To determine the effect } \\
\text { of the insurgency on } \\
\text { Physical, social and eco- } \\
\text { nomic activities of the } \\
\text { residents of Maiduguri, }\end{array}$ & Qualitative & Interview & $\begin{array}{l}\text { Education, mortality, infra- } \\
\text { structure, displacement, } \\
\text { children and women, forced } \\
\text { migration, commercial busi- } \\
\text { ness, unemployment, low } \\
\text { income, poor living condi- } \\
\text { tion, cost of doing business }\end{array}$ & $\begin{array}{l}\text { From our findings, it was ob- } \\
\text { served that the situation and ter- } \\
\text { rorism are not unrelated to pov- } \\
\text { erty, unemployment and mis- } \\
\text { conception of the teaching of the } \\
\text { Holy Quran by some Islamic } \\
\text { "Ulames" }\end{array}$ \\
\hline $\begin{array}{l}\text { Njoku and } \\
\text { Nwachukwu, } \\
2015\end{array}$ & $\begin{array}{l}\text { This study examined the } \\
\text { effects of Boko Haram's } \\
\text { insecurity on the econ- } \\
\text { omy of Nigeria }\end{array}$ & Qualitative & $\begin{array}{l}\text { Online } \\
\text { questionnaire }\end{array}$ & Economy & $\begin{array}{l}\text { The findings established that } \\
\text { ideology and funding are the } \\
\text { compelling key elements that } \\
\text { propelled the Boko Haram sect } \\
\text { in Nigeria, the Boko Haram haz- } \\
\text { ard presents a substantial risk to } \\
\text { Nigeria's economy }\end{array}$ \\
\hline $\begin{array}{l}\text { Othman et al. } \\
2015\end{array}$ & $\begin{array}{l}\text { This study explores the } \\
\text { impact of boko haram on } \\
\text { business entrepreneur- } \\
\text { ship climate in Nigeria }\end{array}$ & Qualitative & Secondary source & $\begin{array}{l}\text { Forced migration, mortality, } \\
\text { commercial business, cost } \\
\text { of doing business, military } \\
\text { spending, unemployment, } \\
\text { education }\end{array}$ & $\begin{array}{l}\text { The findings affirmed that busi- } \\
\text { nesses no longer take place in } \\
\text { the distressed territories such as } \\
\text { the northeast part of Nigeria be- } \\
\text { cause markets were closed, } \\
\text { banking services not provided, } \\
\text { or hours of services reduced }\end{array}$ \\
\hline
\end{tabular}

Table 2. Other socioeconomic effects of Boko Haram insurgency

\begin{tabular}{|c|l|l|}
\hline Sr. no. & \multicolumn{1}{|c|}{ Other socioeconomic effects of Boko Haram insurgency } & \multicolumn{1}{|c|}{ Study } \\
\hline 1 & Fear/anxiety affects some people in the conflict areas & $\begin{array}{l}\text { Afolabi (2015); Awojobi, 2014; Familusi } \\
\text { and Oshomoh, (2018); Mbaya et al., 2017; } \\
\text { Othman et al. (2015) }\end{array}$ \\
\hline 2 & Unemployment increased & Mbaya et al. (2017); Othman et al. (2015) \\
\hline 3 & People abducted still missing & Awojobi (2014); Mbaya et al., (2017) \\
\hline 4 & $\begin{array}{l}\text { The phenomenon of Internally Displaced Persons (IDPs) has become a social issue and } \\
\text { unhealthy for economic development }\end{array}$ & (Familusi and Oshomoh (2018) \\
\hline 5 & $\begin{array}{l}\text { Youth unemployment, bad governance, political corruption and poverty caused Boko } \\
\text { Haram insurgency }\end{array}$ & Afolabi (2015); Awojobi (2014) \\
\hline
\end{tabular}

